\title{
FENOMENA LAGU DOLANAN "GUNDUL-GUNDUL PACUL" DALAM PENDIDIKAN KARAKTER ANAK DAN RANAH SOSIAL
}

\author{
Adi Suprayogi \\ Fakultas Bahasa dan Seni, Universitas Negeri Yogyakarta \\ E-mail: adisuprayogi02@gmail.com
}

\begin{abstract}
Abstrak
Lagu Dolanan mempunyai makna, fungsi, filosofi dan tujuan di setiap liriknya. Media musik melalui lirik lagu dolanan dapat merangsang pertumbuhan emosi anak. Teknik stimulasi melalui lagu dolanan tersebut ternyata memiliki dampak positif bagi pembentukan karakter. Anak dapat terkontrol, baik secara emosi maupun kebiasaan tingkah laku sehari-hari. Lagu Dolanan "GundulGundul Pacul" yang mempunyai makna bahwa saat kita mengemban jabatan ataupun menjadi manusia seutuhnya tidak diperbolehkan "gembelengan" yang berartikan sombong. Dalam bertingkah laku dan mengambil keputusan haruslah hati-hati dan jangan gegabah, jika semua tidak dipenuhi semua akan hancur berantakan tidak beraturan, bahkan kita tidak mendapatkan suatu makna apapun. Pemaknaan lagu dolanan dapat membantu anak dalam menggali nilai-nilai kehidupan, pendidikan, rasa hormat serta sopan santun kepada orang tua dan memegang teguh erat kebudayaan mereka sebagai identitas bangsa.
\end{abstract}

Kata kunci: dolanan, gundul, pacul, musik, karakter, anak

\section{“GUNDUL-GUNDUL PACUL" SONG PHENOMENON IN CHARACTER EDUCATION OF CHILDREN AND SOCIAL REALM}

\begin{abstract}
Dolanan songs have meaning, function, philosophy, and purpose in their lyrics. Music media through song lyrics can stimulate children's emotional growth. The stimulation technique through the song is apparently a positive impact on character formation. Children can be controlled, both emotionally and in their everyday behavior. The song Dolanan "Gundul-Gundul Pacul" which means that when we take office or become fully human is not allowed to be "gembelengan" which means arrogant. In behaving and making decisions, we must be careful and not careless, if all is not fulfilled, all will fall apart irregularly, and even we will not get any meaning. The meaning of dolanan songs can help children explore the values of life, education, respect, courtesy to their parents, and hold fast to their culture as a national identity.
\end{abstract}

Keywords: dolanan, gundul, pacul, music, character, child

\section{PENDAHULUAN}

Kebudayaan Indonesia sangatlah beragam jenisnya, dari Sabang sampai Merauke yang terdiri dari 34 provinsi. Di setiap daerah tersebut mempunyai kebudayaan khas daerah masing-masing yang perlu di pertahankan dan dilestarikan untuk saat ini. Leluhur atau nenek moyang banyak menciptakan sebuah karya dalam bentuk lagu atau tembang, tarian, serat, permainan dolanan anak dan lainlain. Berbagai macam karya leluhur tersebut diciptakan tidak hanya sekedar menyeratkan sebuah tinta, akan tetapi perlu ikhtiar, laku dan disertai dengan peristiwa tertentu. Sehingga, 
sebuah tetembangan tersebut mempunyai makna yang mendalam serta filosofi sebagai pesan tersendiri untuk generasi kedepannya. Woodward (2007: 4) mengemukakan bahwa, "Object are commonly spoken of as material culture emphasis how apparently inanimate things within the environment act on people, and are acted upon by people, for the porposes of carrying out social functions, regulating social relations and giving syimbolic meaning to human activity." (Object biasanya dibicarakan sebagai kebudayaan material. Istilah kebudayaan material menekankan bagaimana benda-benda mati diantara tindakan lingkungan orang-orang dan diperlakukan orang-orang, bertujuan untuk membawa fungsi sosial, mengatur hubungan-hubungan sosial, dan memberikan arti simbolis pada aktivitas manusia).

Berbagai macam objek atau benda-benda yang menyangkut materi kebudayaan tersebut mempunyai makna dan tujuan, serta mampu berinteraksi secara sosial. Materi kebudayaan membawa pesan atau fungsi sosial secara simbolis dalam berbagai tujuan kepada masyarakat ataupun anak cucu dan generasi kedepannya. Menurut Ki Hajar Dewantara menyatakan bahwa, "kultur atau kebudayaan itu artinya sama dengan pengertian usaha perbaikan hidup manusia. Serta kebudayaan merupakan tanda dan ukuran tentang tinggi rendahnya keadaban dari masing-masing bangsa".

Kultur atau kebudayaan adalah suatu langkah-langkah perbaikan untuk menjadikan bangsa tersebut menjadi lebih baik. Tingkat ukuran kemakmuran dan keadaban suatu bangsa dapat diukur dari tingkat peradaban dalam kebudayaan sebuah bangsa. Globalisasi yang kita alami pada saat ini, pastilah terdapat pengaruh baik buruk bagi kita sendiri. Teruntuk bagigenerasi penerus bangsa, banyak anak-anak pada saat ini tidak mengenal dengan budaya mereka. Mereka tidak mengenal budaya leluhur mereka, baik itu lagu dolanan, tetembangan, tarian dan sebagainya yang berkaitan dengan budaya. Mereka menganggap hal tersebut ndeso dan ketinggalan jaman. Fenomena ini sangatlah yang mengerikan dan menakutkan, karena berbagi macam materi kebudayaan dari nenek moyang tersebut terdapat pesan-pesan sosial, mempunyai nilai budi pekerti yang baik, persatuan dan kesatuan serta sangatlah berperan penting bagi pendidikan karakter anak maupun perkembangan emosi anak. Menurut Sudebyo - Budayawan dan Pengamat Pendidikan (2018) mengatakan bahwa, "Anak sekarang yang asik dengan laptop, handphone, $\mathrm{dsb}$. Anak hanya asyik dengan dirinya masingmasing. Bisa dikatakan kalo generasi sekarang ini adalah keadaannya tidak baik. Anak tidak mengenal budaya mereka, adat mereka, budi pekerti dan nilai-nilai budaya. Di dalam proses pembelajaran tersebut, anak mendapatkan ilmu serta dididik. Dididik konteksnya meliputi segala aspek, baik dari kepribadian anak, tingkah laku dan pengenalan unggah ungguh atau tingkah laku sopan santun".

Di era globalisasi pada saat ini, anak asyik dengan handphone, laptop, gadget, game dan asyik dengan dirinya sendiri. Dipandang secara pendidikan karakter dan perkembangan emosi anak sangatlah tidak baik. Anak menjadi tidak mengenal budaya mereka, adat mereka, budi pekerti yang baik. Fenomena ini sangatlah ditakutkan bagi sebuah bangsa, karena menyangkut generasi dan identitas sebuah bangsa. Era Pendidikan di Indonesia sendiri terdapat kehilangan pendidikan karakter dan pengenalan kebudayaan masingmasing daerah, dikarenakan dihilangkannya pembelajaran Bahasa Daerah atau Muatan Lokal. Hal tersebut sangatlah disayangkan dan pemerintah, khususnya dinas pendidikan baru menyadari efek dari peristiwa tersebut berpengaruh diaspek pendidikan karakter, kebudayaan, identitas bangsa dan sebagainya.

Lagu Dolanan Jawa mempunyai tujuan dan makna tertentu dalam anak belajar dan bermain. Anak dikenalkan dengan budi pekerti, unggah ungguh atau sopan santun, unsur kebersamaan, adat budaya serta nilai-nilai budaya yang terkandung dalam lagu dolanan tersebut. Di usia mereka berkembang, keluarga dan lingkungan sangatlah berpengaruh penting dalam proses pendidikan karakter anak. 
Ki Hadjar Dewantara dalam bukunya yang berjudul Sari Swara mengatakan: bahwa pelajaran tembang (sekar) atau gending Jawa untuk anak Jawa itu, amat besar memberikan kekuatan dalam membentuk budi perkerti yang halus, memantapkan rasa kebangsaan serta menguasai dalam belajar sastra. Oleh karena itu di Negara manapun juga, pelajaran tembang itu dalam pelajaran termasuk masalah yang amat diperhatikan.

Akan tetapi di era milenial sekarang ini, banyak anak yang sudah mengenal gadget, dunia luar, pengetahuan-pengetahuan di luar batas tanpa sepengetahuan dan pengawasan orang tua. Orang tua tidak mau repot-repot mengasuh anak dan mendidik anak, missal pun anak mereka rewel. Orang tua lebih baik memilih memberikan anak mereka handphone, laptop serta gadget lainnya agar anak asyik dengan apa yang anak tonton. Fitur Youtube yang mereka buka mungkin hanyalah kartun, tapi efek yg diberikan sangatlah tidak baik dari segi kesehatan mata maupun pendidikan. Handphone yang anak pegang dengan bebasnya membuka layanan fitur yang ada di handphone tersebut. Pendidikan karakter dan pembentukan emosi anak tidak dapat tersampaikan dengan baik, jika pendidikan tersebut hanya diperoleh dari sekolah saja hasilnya tidak akan maksimal dengan ditambah pendidikan tentang kebudayaan tidak diajarkan. Lalu bagimanaka generasi penerus bangsa kita untuk saat ini dan kedepannya. Pemerintah dan juga masyarakat baru tersadar dengan adanya berbagai kasus yang terjadi dari hari ke hari. Permasalahan tersebut selalu menyelimuti atau menyinggung tentang pendidikan karakter, budi pekerti, kebudayaan, persatuan, integritas bangsa, identitas bangsa. Sebagai contohnya, terdapat kasus anak membunuh orang tua, tawuran, perang saudara, klaim budaya secara sepihak, serta tidak menggunakan gadget secara baik dan benar. Kita tersadar dan baru kebakaran jenggot setelah semua sudah terjadi. Menurut Zuchdi dkk. (2015 : 13) ;mengemukakan bahwa, "Sikap dan perilaku masyarakat dan bangsa Indonesia sekarang cenderung mengabaikan nilai-nilai luhur yang sudah lama dijunjung tinggi dan mengakar dalam sikap dan perilaku seharihari. Nilai Karakter mulia, seperti kejujuran, kesantunan, kebersamaan, dan religius, mulai tergerus dengan budaya asing yang cenderung hedonistik, materialistik, dan individualistik. Pengaruh globalisasi mengakibatkan masyarakat dan bangsa Indonesia menjadi pribadi yang mempunyai sikap dan perilaku mengabaikan nilai-nilai luhur yang mempunyai sifat dan perilaku sangat mulia. Nilai-nilai luhur tersebut sangat dijunjung tinggi oleh genarasigenerasi sebelumnya, akan tetapi untuk saat ini masyarakat banyak yang sudah melupakannya. Mereka menganggap paham-paham budaya leluhur itu sesuatu yang ketinggalan jaman dan kolot.

Fokus masalah adalah pada kebudayaan terkhusus pada hubungan pengaruh Lagu Dolanan terhadap pendidikan karakter anak dan ranah sosial. Melalui Lagu dolanan tersebut diharapkan anak mampu terstimulus dari makna dan arti dari tembang tersebut, merangsang imajinasi dan emosi anak beserta mampu memenuhi nilai-nilai dan aspek-aspek pendidikan karakter.

Fenomena berasal dari bahasa Yunani; phainomenon, berartikan apa yang terlihat, fenomena juga dapat diartikan: suatu gejala, fakta, kenyataan, kejadian dan hal-hal yang dapat dirasakan dengan panca indra bahkan hal-hal yang mistik atau klenik. Kata fenomena dapat diartikan juga sesuatu yang luar biasa. Fenomena terjadi di semua tempat yang dapat diamati oleh manusia. Suatu kejadian atau peristiwa yang terjadi adalah suatu fenomena. Suatu benda merupakan suatu fenomena, karena merupakan sesuatu yang dapat dilihat dan diamati. Adanya suatu benda juga menciptakan keadaan ataupun perasaan yang tercipta karena keberadaannya. Fenomena adalah rangkaian peristiwa serta bentuk keadaan yang dapat diamati dan dinilai baik secara ilmiah maupun non ilmih.

Haryono Suyono dalam Aria Gautama (2011: 12) diartikan cara pendekatan ilmiah yang mempersoalkan sebab-sebab timbulnya gejalaatau kejadiansemata-mata tanpa mencoba menerangkannya. Dengan demikian dari 
pengertian-pengertian di atas dapat dinyatakan bahwa fenomena adalah suatu peristiwa tidak lazim yang terjadi di masyarakat yang dapat dilihat, dapat dirasakan dan dapat diamati oleh manusia sehingga menarik untuk dikaji atau diteliti keadaannya baik secara ilmiah maupun non ilmiah.

Fakta, kenyataan, gejala sebab akibat, kejadian atau peristiwa yang dapat berwujud serta dapat dirasakan, diamati diteliti dan dikaji oleh manusia baik secara ilmiah maupun non ilmiah, istilah tersebut dinamakan fenomena. Didalam kehidupan manusia sangat lah banyak kejadian-kejadian suatu fenomena yang menurut masyarakat tidak lazim dan kontras terhadap kebiasaan, tingkah laku dan gaya hidup mereka. Sebagai contohnya Fenomena Sumanto, manusia kanibal asal Pelumutan pada tahun 2003 silam.Fenomena Sumanto tersebut sangatlah kontra dan mencolok bagi masyarakat di Indonesia, karena Sumanto mempunyai kebiasaan aneh yaitu mencuri mayat kemudian memakan mayat manusia tersebut. Kejadian tersebut Sumanto lakukan sebanyak dua kali, yaitu sebaktu dia tinggal berada di Lampung dan Purbalingga. Dipercayai Sumanto melakukan hal tersebut karena sebuah kepercayaan ajaran ilmu hitam. Hal ini bagi masyarakat adalah sesuatu yang menggemparkan bagi mereka, karena sesuatu yang tidak biasa dan sangatlah tidak terpuji tidak sesuai norma-norma dan kodrat sebagai manusia seutuhnya.

Lagu Dolanan adalah tetembangan atau nyanyian saat masyarakat Jawa, khususnya anak-anak bermain bersama teman-teman. Menurut Nurgiyanto dalam Febriyanto (2005: 108) mengatakan bahwa, lagu dolanan adalah jenis lagu berstruktur geguritan yang tidak terikat aturan baku, karena strukturnya tidak termasuk dalam kategori jenis tembang Macapat. Sementara itu Danandjaja dalam Mack mengutarakan (1995: 13), lagu yang bersifat folklore mempunyai ciri-ciri sebagai berikut.

a. Penyebaran dan pewarisnya biasanya dilakukan secara lisan. b. Folklor ada dalam versi bahkan varian yang berbeda.

c. Folklor bersifat anonim

d. Folklor biasanya memiliki struktur, berumus, atau berpola

e. Folklor memiliki kegunaan dalam kehidupan bersama

f. Folklor memiliki ciri pralogis

g. Folklor menjadi milik bersama

h. Folklor umumnya bersifat polos dan lagu

Peryataan tersebut menandakan bahwa Lagu Dolanan merupakan suatu bentuk lagu yang berstruktur bebas, sederhana dan tidak terikat oleh aturan-aturan baku seperti bentuk Macapat. Lagu dolanan tersebut memiliki ciri, yaitu bersifat anonim, berstruktur, bersifat sederhana, disebarkan secara lisan dan memiliki kegunaan dalam kehidupan.Lagu dolanan mempunyai pesan, makna dan tujuan fungsi sosial tertentu di dalamnya. Melalui nyanyian anak akan dengan mudah terstimulus dan menerima apa pesan yang terkandung dalam lagu dolanan tersebut. Rosmiyati (2014) mengatakan bahwa "...teknik stimulasi melalui musik ini membuat anak memiliki sifat perangai yang riang. Anak bisa bergerak leluasa dengan iringan musik sambil menyanyikan lirik lagunya. Secara emosi terbentuk karakter yang baik pada memorinya. Media pembelajaran melalui musik dirasa lebih efektif dan efsien bisa dimengerti dan dihafal oleh anak-anak".

Media pembelajaran melalui musik dianggap mampu lebih efektif dan efisien menstimulus menjadi pribadi yang riang bergerak leluasa dengan iringan musik beserta menyanyikan lagu tersebut. Pesan dan nilai-nilai yang terkandung dari tetembangan atau lagu tersebut dapat dengan mudah tersampaikan dan diingat oleh anak-anak. Diharapkan pendidikan karakter seperti, budi pekerti, perkembangan emosi, nilai-nilai luhur maupun budaya yang dituju sesuai dengan harapan dan hasil yang maksimal. Menurut Kajian permainan anak menurut Ahimsha (1999: 15) dalam Hermawati (2015), dapat dilihat dari berbagai perspektif sebagai berikut.

a. Perspektif Fungsional: persiapan menjadi dewasa 
b. Perspektif bermain: permainan 'game'

c. Persepektif Psikologis: wujud kecemasan dan kemarahan

d. Persepektif Adaptasi: peningkatan kemampuan adaptasi

Lirik lagu merupakan bagian dari sebuah lagu yang bercirikan memiliki sajak, berbait, dan berisikan tentang sebuah makna atau ungkapan-ungkapan perasaan serta suatu pesan dari pengaring berdasarkan pengalaman pribadi pengarang maupun pengalaman pribadi orang lain yang ingin dituangkan ke dalam lagu tersebut. Lirik berasal dari kata "lyric" yang memiliki kaidah-kaidah sastra umumnya terdiri dari bait-bait, memiliki bahasa puitis juga berhubungan erat dengan kaidah-kaidah filsafat tertentu dan merupakan ungkapan perasaan pengarang berdasarkan pengalaman dirinya maupun orang lain (Tambayong 1992: 56).Kajian semiotik digunakan untuk menjelaskan nilai makna atau pesan yang terkandung di dalam dolanan anak. Semiotik merupakan bagian keilmuan yang dicetuskan oleh Ferdinand de Saussure (linguist) serta Roland Barthes (sastrawan). Ilmu penanda dan petanda yang dikenal sebagai semiotik digunakan untuk menjelaskan makna yang selain kata yang diungkapkan, misalnya benda, gerakan, atau simbol. Pada kajian ini akan mengggunakan pendapat Barthes (1970:1920), yang membagi kode menjadi lima, yakni a) Kode hermeneutik, b) Kode semik, c) Kode simbolis, d) kode aksi, dan e) Kode kultural. Adapun kajian yang akan diangkat berupa nilai karakter di dalam dolanan anak maka akan lebih relevan apabila menggunakan kode simbolis dan kode kultural.

Karakter merupakan sifat yang tampak dari seseorang saat berbicara atau bertingkah laku dalam kehidupan sehari-hari. Karakter dapat dibangun melalui penanaman baik langsung maupun tidak langsung. Melalui dolanan anak, nilai karakter dapat diberikan kepada anak, misalnya nilai sportivitas, nilai pendidikan, nilai gotong royong, nilai moral, dan nilai keberanian (Sujarno, dkk, 2011: 119).

Pengenalan lagu dolanan "Gundul-Gundul Pacul" diharapkan anak dapat memahami dan memetik nilai-nilai yang terkandung dalam lirik lagu serta berperilaku dalam kehidupan seharihari sesuai dengan tujuan pendidikan karakter. Anak mempunyai sopan santu, budi pekerti luhur, kebersamaan, nilai moral yang baik, keberanian dan nilai sportivitas yang tinggi. Yang dimaksudkan manusia yang mempunyai pendidikan karakter sendiri adalah, orang yang berkepribadian, berperilaku, bersifat, bertabiat dan berwatak. Dengan makna seperti ini berarti karakter identik dengan kepribadian dan watak. Kepribadian merupakan ciri atau karakteristik atau sifat khas dari seseorang yang bersumber dari bentukan-bentukan yang diterima dari di lingkungan, misal keluarga pada masa kecil, dan juga bawaan sejak lahir (Koesoema, 2007: 80). Selanjutnya Lickona dalam Zuchdi menambahkan "Character so conceived has three interrelated parts: moral knowing, moral felling, and moral bihaviors" (Lickona, 1991: 51). Karakter manusia mengacu pada serangkaian bagian yang saling berhubungan yaitu pemikiran (cognitivves), perasaan (affectives) dan perilaku kebiasaan sehari-hari (habits). Pada akhir-akhir ini sangat ramai diperbincangkan di tengah-tengah masyarakat Indonesia, terutama dalam konteks kalangan akademisi. Sikap dan perilaku masyarakat Indonesia mengabaikan nilai-nilai luhur dan mereka sangat bangga mempunyai gaya hidup westernisasi, yaitu gaya hidup berkiblat budaya Eropa. Hal tersebut sangat bertolak belakang dari segala aspek untuk orang timur sendiri, khususnya Indonesia. Masyarakat Indonesia baik di daerah-daerah mulai malu dengan budaya merekan dan mulai meninggalkannya. Fenomena ini sangat ditakutkan bagi sebuah bangsa, karena berkaitan dengan integritas dan identitas bangsa tersebut.

\section{PEMBAHASAN}

Lagu dolanan anak tradisional sangat dikenal di masyarakat terutama kalangan anak anak pada masa tahun 80 -an. Hal tersebut disebabkan anak-anak memiliki waktu luang dan tempat untuk bernyanyi dan bermain bersama teman-teman. Anak-anak pada masa tahun tersebut banyak memiliki waktu luang 
sepulang sekolah, karena belum disibukan dengan aktifitas kegiatan les dan mata pelajaran seperti saat ini. Apalagi saat ini ditambah diadakannya system pembelajaran fullday school. Sehingga, waktu mereka sudah habis hanya terkurung didalam sekolah. Disamping itu, anak-anak pada masa itu belum dikenalkn permainan atau games yang sangat beraneka ragamnya seperti saat ini. Jadi, anak-anak di era 80 -an bermain dengan fasilitas yang ada di sekitar mereka. Kebanyakan anak-anak bermain secara bersama-sama berkumpul di depan halaman rumah pada saat sore hari atau saat bulan purnama bersinar. Merekan berkumpul untuk memainkan dan dan menyanyikan aneka permainan serta tembang yang mereka suka. Sebagi contohnya, bermain petak umpet pada saat sore hari atau bulan purnama tiba, kemudian mereka menyanyikan lagu-lagu dolanan sebagai pengecoh penunggu dalam permainan tersebut.
Pendidikan sangat penting dalam menentukan perkembangan dan perwujudan diri individu, khususnya bagi perkembangan masyarakat, bangsa, dan negara. Dengan mengenali, menghargai, dan memanfaatkan sumber daya manusia yang terdapat dalam anggota masyarakat. Hal ini akan menentukan kemajuan budaya suatu bangsa. Untuk dapat mencapai pendidikan melalui lirik atau syair lagu dolanan anak tradisional, dapat dilakukan melalui lembaga pendidikan. Disebutkan dalam Higher Education Long Term Strategy 2003-2010, bahwa seni yang berakar dari tradisi dan budaya lokal, merupakan faktor krisis dalam pengembangan karakter bangsa, serta pengembangan individu yang kreatif dan inovatif. Sebagai kajiannya lagu dolanan "Gundul-Gundul Pacul" menjadi salah satu contoh sampel dari berbagai macam lagu dolanan.

\section{Kajian Makna dan Arti}

Berikut adalah lirik dan notasi lagu "Gundul-Gundul Pacul" :

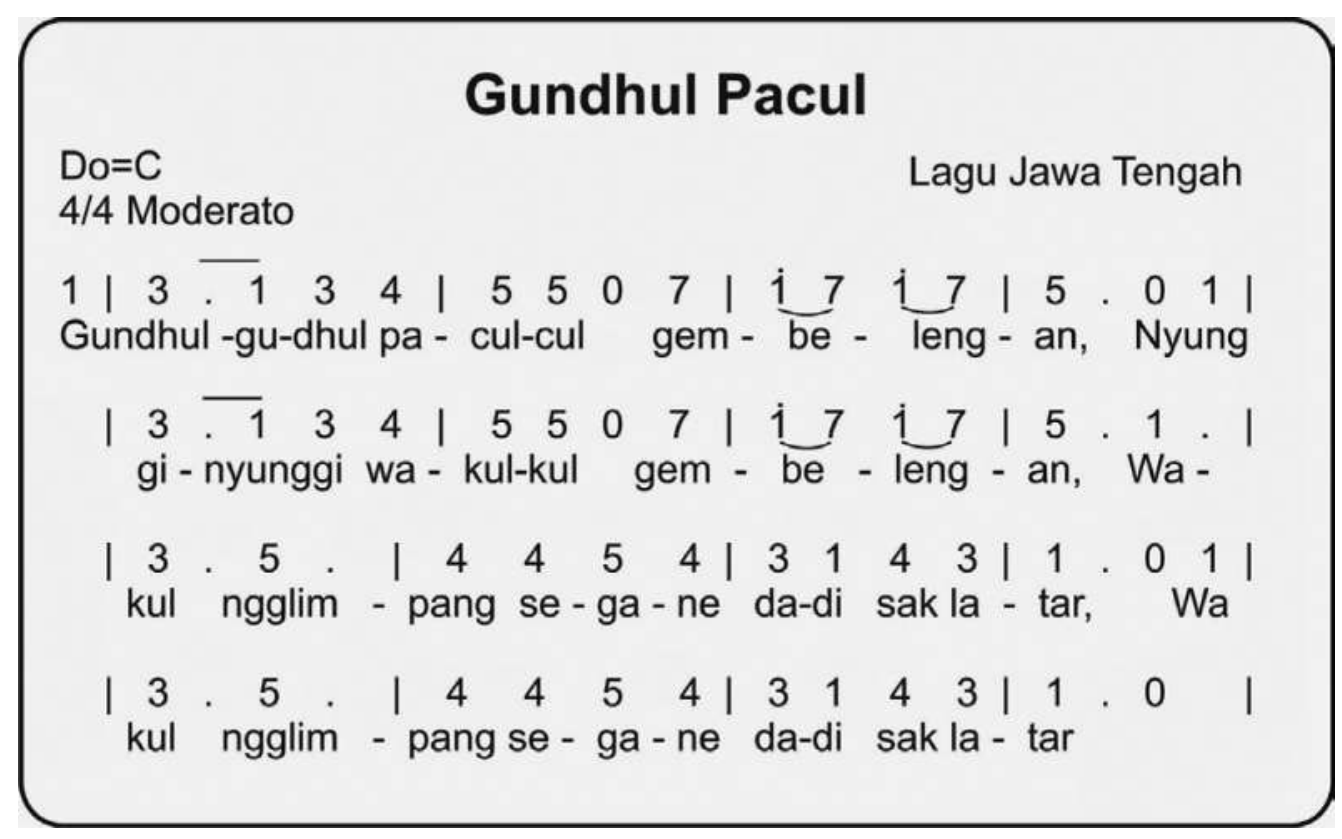

Makna dari lagu "Gundul-Gundul Pacul" menurut Purwadi dkk. (2005: 95) menyatakan bahwa lagu "Gundul-Gundul Pacul" menyarankan agar orang tetap menjaga kesahajaan, keluguan, kepolosan, dan kejujuran.
Tidak boleh tampil pongah, sombong, congkak yang membuat orang lain sakit hati. Itulah jalan damai untuk pergaulan.

Lagu diatas mempunyai pesan yang selalu mengingatkan kita dengan sesuatu hal 
yang berkaitan dengan perilaku luhur. Kata "gundul" sendiri bermakna kepala, dapat diartikan juga ketika kita menjadi tokoh dalam masyarakat, baik itu sosok ketua dalam masyarakat atau pemimpin dalam keluarga. Tidak diperkenankan untuk berbuat sombong, semena-mena, semaunya sendiri, congkak atau perbuatan yang dapat membuat orang lain sakit hati. Semua akan menanggung akibatnya jika kita tidak berhati-hati dalam bertindak, baik untuk diri kita ataupun orang disekitar kita akan merasakan efeknya. Berikut adalah hasil wawancara dengan berbagai sumber yang berkaitan dengan aspek-aspek dalam pendidikan karakter dan kebudayaan di kabupaten Magelang :

\begin{tabular}{ll}
\hline \multicolumn{1}{c}{ Pertanyaan } & \multicolumn{1}{c}{$\begin{array}{c}\text { Wawancara } \\
\text { Deby }\end{array}$} \\
\hline Sejak kapan Lagu & "Waduh, tepatnya kapan \\
Dolanan tersebut & saya tidak tahu, yang saya \\
muncul? & amati di literatur siapa dan \\
& kapannya lagu diciptakan \\
& tertera $N N$ atau non-name \\
& dan kebetulan saya kecil \\
& bukan di era lagu dolanan \\
& tersebut".
\end{tabular}

Makna dan tujuan

lagu dolanan

"Gundul-Gundul

Pacul"?

\begin{abstract}
"Intinya sepemahaman saya, jadi orang jangan gembelengan, banyak gaya dan sombong. Tapi untuk kepastian bener ngga nya, saya kurang paham mas".
\end{abstract}

Bagaimana peran lagu dolanan dalam dunia pendidikan?

\author{
"Menurut saya didalam \\ lagu dolanan tersebut, \\ masing-masing mempunyai \\ filosofi dan pesan-makna \\ tertentu didalamnya, tapi \\ anak sekarang banyak yang \\ ngga tau mas. Mungkin juga \\ faktor lingkungan juga tidak \\ memperkenalkannya mas, \\ lingkungan disini keluarga \\ maksudnya".
}

$\begin{array}{cc}\text { Wawancara } & \text { Wawancara } \\ \text { Bapak Sudebyo } & \text { Bapak Tukiman }\end{array}$

"Tidak diketahui pastinya kapan, sejak jaman saya sudah ada. Lagu Dolanan sudah diwariskan sejak nenek moyang jaman dahulu, diwariskan secara turun-temurun disetiap generasinya.

Kemungkinan sejak penjajahan Belanda lagu dolanan tersebut sudah ada" kecil lagu dolanan tersebut

"Lagu Dolan tidak diketahui tepatnya dibuat itu kapan, karena tembang-tembang seperti itu dibuat oleh nenek moyang pada jaman dahulu. Mereka membuat tetembangan tersebut tidak hanya sekedar menyerat tinta, tetapi disertai dengan ikhtiar, laku dan disertai dengan peristiwa tertentu. Sehingga, sebuah tetembangan tersebut mempunyai makna yang mendalam serta filosofi sebagai pesan tersendiri untuk generasi kedepan." $\begin{array}{ll}\text { "Menurut versinya dalam } & \text { "Lagu Gundul-Gundul } \\ \text { proses mendidik anak } & \text { Pacul mempunyai makna }\end{array}$ Gundul-gundul Pacul tersebut mempunyai filosofi yang berartikan jadi orang itu tidak boleh sombong, harus hati-hati dalam bertindak dan rendah hati. Wakul bisa ngglimpang yang berartikan, beban atau tanggung jawab yang kita emban tidak hati-hati dalam bertindak, semua akan berantakan". tersendiri, yaitu jadi orang jangan lah sombong, haruslah hati-hati karena semua akan menerima akibatnya dari perilaku tersebut. Wakul Ngglimpang yang berartikan kehilangan sandang dan pangan, jadi untuk mendapatkan kehidupan yang baik serta selamat haruslah tetap hatihati dan waspada dalam bertindak."

$\begin{array}{ll}\text { "Lagu Dolanan mempunyai } & \text { "Didalam makna Lagu } \\ \text { arti dan filosofi tertentu } & \text { Dolanan tersebut } \\ \text { yang berperan penting } & \text { mengandung pesan nilai- } \\ \text { dalam pendidikan karakter } & \text { nilai budi pekerti, unggah } \\ \text { anak. Dalam membangun } & \text { ungguh atau tata karma, } \\ \text { emosi anak atau olahrasa, } & \text { terdapat unsur kesatuan dan } \\ \text { membiasakan anak tampil } & \text { kebersamaan. Sehingga, } \\ \text { dihadapan orang banyak dan } & \text { sangat berperan penting } \\ \text { menjadikan anak tersebut } & \text { dalam pendidikan karakter } \\ \text { berani dan bisa membangun } & \text { anak." } \\ \text { leadership kepada anak". } & \end{array}$




\begin{tabular}{|c|c|c|c|}
\hline $\begin{array}{l}\text { Bagaimana } \\
\text { pendidikan karakter } \\
\text { anak saat ini sebagai } \\
\text { generasi penerus } \\
\text { bangsa? }\end{array}$ & $\begin{array}{l}\text { "Dari pengamatan saya } \\
\text { banyak anak sekarang yang } \\
\text { tidak mempunyai dan tidak } \\
\text { mengerti akan tentang budi } \\
\text { pekerti yang baik. Banyak } \\
\text { kasus-kasus baik ditelevisi } \\
\text { atau di media masa, } \\
\text { seperti anak membunuh } \\
\text { orangtuanya, pecurian } \\
\text { dibawah umur, tawuran, dan } \\
\text { kasus-kasus lainnya tentang } \\
\text { anak. Sungguh miris!!!". }\end{array}$ & $\begin{array}{l}\text { "Anak sekarang yang asik } \\
\text { dengan leptop, hand phone, } \\
\text { dsb. Anak hanya asyik } \\
\text { dengan dirinya masing- } \\
\text { masing. Bisa dikatakan } \\
\text { kalo generasi sekarang } \\
\text { ini adalah keadaannya } \\
\text { tidak baik. Karena, kita } \\
\text { kehilangan beberapa } \\
\text { generasi yang dimaksudkan } \\
\text { bahwa beberapa generasi } \\
\text { tersebut tidak mendapatkan } \\
\text { pendidikan karakter. Sebagai } \\
\text { contohnya, dihilangkannya } \\
\text { Bahasa Daerah dalam proses } \\
\text { pembelajaran. Sehingga, } \\
\text { anak tidak mengenal budaya } \\
\text { mereka, adat mereka, } \\
\text { dan nilai-nilai budaya. Di } \\
\text { dalam proses pembelajaran } \\
\text { tersebut, anak mendapatkan } \\
\text { ilmu serta dididik. Dididik } \\
\text { konteksnya meliputi segala } \\
\text { aspek, baik dari kepribadian } \\
\text { anak, tingkah laku dan } \\
\text { pengenalan unggah ungguh } \\
\text { atau tingkah laku sopan } \\
\text { santun". }\end{array}$ & $\begin{array}{l}\text { "Berkaitan dengan } \\
\text { pendidikan karakter, anak- } \\
\text { anak dijaman sekarang } \\
\text { tidak mengerti tentang budi } \\
\text { pekerti yang baik, unggah } \\
\text { ungguh atau tata karma } \\
\text { sopan santun yang baik. }\end{array}$ \\
\hline $\begin{array}{l}\text { Bagaimana pendapat } \\
\text { anda langkah- } \\
\text { langkah untuk } \\
\text { mempertahankan } \\
\text { eksistensi lagu } \\
\text { dolanan dalam nilai- } \\
\text { nilai budaya? }\end{array}$ & $\begin{array}{l}\text { "Masyarakat beserta } \\
\text { pemerintah harus lebih } \\
\text { menggalakkan lagi tentang } \\
\text { budaya, seperti lagu dolanan } \\
\text { tersebut. Karena mempunyai } \\
\text { pengaruh dan dampak yang } \\
\text { positif terhadap pendidikan } \\
\text { anak di Indonesia dan } \\
\text { budaya sendiri merupakan } \\
\text { Identitas suatu bangsa. } \\
\text { Seharusnya kita bangga } \\
\text { dan melestarikan budaya } \\
\text { tersebut". }\end{array}$ & $\begin{array}{l}\text { "Pemerintah dan masyarakat } \\
\text { harus lebih menggalakkan } \\
\text { lagi budaya masing-masing, } \\
\text { baik di bidang pendidikan } \\
\text { maupun di masyarakat. } \\
\text { Di Magelang sendiri } \\
\text { terdapat "PERMADANI" } \\
\text { (Persaudaraan Masyarakat } \\
\text { Budaya Nasional } \\
\text { Indonesia) yang menaungi } \\
\text { pembelajaran sastra dan } \\
\text { budaya jawa, dalam rangka } \\
\text { Nguri-uri Budayauntuk } \\
\text { mempertahankan eksistensi } \\
\text { budaya Jawa tersebut dan } \\
\text { pemerintah dinas pendidikan } \\
\text { mengadakan lomba-lomba } \\
\text { lagu dolanan serta yang } \\
\text { berkaitan tentang budaya } \\
\text { tradisional yang khususnya } \\
\text { di Magelang". }\end{array}$ & $\begin{array}{l}\text { "Untuk menggali dan } \\
\text { melestarikan kebudayaan } \\
\text { bangsa tersebut dengan cara } \\
\text { mengadakan khursus atau } \\
\text { pembelajaran budaya dan } \\
\text { satra Jawa "PERMADANI" } \\
\text { dan mengadakan perlombaan } \\
\text { tentang lagu dolanan dan } \\
\text { kebudayaan." }\end{array}$ \\
\hline
\end{tabular}

Narasumber yang diwawancarai adalah narasumber yang terkait dengan pendidilan karakter dan budaya, khususnya di masyarakat kabupaten Magelang. Melalui ovservasi, survai kemudian wawancara. Dari data yang di amati, masyarakat di jaman sekarang sudah tidak peduli dengan budaya terutama lagu dolanan.
Di lingkungan masyarakat, sosok orang tua adalah pondasi tumbuh kembangnya anak. Pada zaman dahulu, anak-anak dinyanyikan atau didongengkan sebuah cerita bahkan ada obrolan antara orang tua dengan anak tentang cita-cita anak atau juga pesan-pesan orang tua kepada anaknya sebagai tuntunan sebelum tidur. Di era 
jaman milenial saat ini, banyak anak-anak yang lebih mengenal dan suka dengan budaya orang lain. Sebagai contohnya, banyak masyarakat di Indonesia yang lebih mengikuti dan lebih mencintai K-Pop. Pengaruh Korean Popular tersebut membuat anak-anak di Indonesia mengikuti style atau cara berpenampilan ala artis korea, khususnya bagi remaja putri. Skala anak usia dini hingga dewasa banyak yang hafal lagu maupun gerakan dari $K$-Pop tersebut. Secara tidak sadar kita dibuat harus mempelajari bahasa, budaya, gaya hidup orang korea dan kita menjadi mengagungagungkan menganggap orang korea itu lebih baik dari kita. Kita dibuat agar melupakan dan meninggalkan budaya kita, banyak anak-anak muda beranggapan kalo budaya Indonesia itu ndeso dan ketinggalan jaman. Nah, ini sangat berpengaruh di segala aspek bagi sebuah bangsa, baik itu integritas dan juga identitas suatu bangsa.

Di jaman perkembangan teknologi saat ini yang amat pesat, kita dimanjakan dengan system dan membuat kita malas dan enggan untuk berproses. Di lingkungan masyarakat banyak orang tua yang tidak mau repot, pendidikan anak hanya pasrah dengan sekolah. Hal tersebut merupakan menjadi kambing hitam dalam proses pendidikan. Pendidikan anak pastilah melibatkan berbagai pihak, tidak hanya disekolah saja. Pendidikan karakter anak ditentukan juga dari lingkungan anak tinggal, keluarga menjadi pembentuk karakter atau watak anak dalam proses pertumbuhan. Sehubungan dengan hal tersebut, bagaimanakah generasi bangsa kita selanjutnya jika kita hanya akan selalu bangga dengan budaya bangsa lain. Dan juga kita tidak mencintai serta melestarikan budaya untuk anak cucu kita.Ini merupakan suatu tugas untuk kita masing-masing, karena berpengaruh terhadap eksistensi dan keberadaan bangsa Indonesia.

\section{KESIMPULAN}

Lagu dolanan mempunyai pengaruh dalam proses pendidikan karakter anak. Di setiap lagu dolanan mempunyai makna, arti serta pesan tertentu didalam liriknya.
Mempunyai dampak yang positif dalam prosaes pembentukan karakter dan watak anak. Pesan-pesan yang terkandung dalam lirik lagu dolanan mengajarkan tentang budi pekerti, sopan santun, budaya, tuntunan dalam menjalani kehidupan sehari-hari dan menjauhi sesuatu yang kurang baik dalam bertindak. Melalui lagu dolanan anak akan terstimulus mudah mengingat makna yang terkandung dari lagu tersebut dan juga membentuk emosi anak menjadi pribadi yang riang dan pemberani. Di dlam lagu dolanan "Gundul-Gundul Pacul" ini mempunyai makna yaitu mengingatkan kita untuk tidak sombong, congak, hati-hati dalam bertindak agar semua yang kita jalani atau kita lakukan berhasil, selamat sesuai dengan keinginan kita.

Akan tetapi yang menjadi permasalahan adalah, banyak anak-anak yang sudah tidak mengenal dan mengerti tentang lagu dolanan. Dilingkungan masyarakat banyak orang tua yang tidak mau repot, pendidikan anak hanya pasrah dengan sekolah. Pendidikan karakter anak ditentukan juga dari lingkungan anak tinggal, keluarga menjadi pembentuk karakter atau watak anak dalam proses pertumbuhan anak.

\section{DAFTAR PUSTAKA}

Purwadi. 2015. Tembang Dolanan. Yogyakarta: LARAS MEDIA PRIMA

Zuchdi,Damayanti.2015.Pendidikan Karakter. Yogyakarta: UNY PRESS

Tauchid. Moch. Karja Ki Hadjar Dewantara. Yogyakarta: Pertjetakan Taman-Siswa

Rosmiyati, Ana. 2014. Teknik Stimulasi dalam Pendidikan Karakter Anak Usia Dini melalui Lirik Lagu Dolanan dalam journal "Resital" vol. 15 no. 1

Maladi I., Agus. 2016. Development of Jatilan Performance as an Adaptive Strategy Used by Javanese Farmers. Dalam Jurnal Arts and Research Art, Vol. 16, No. 1, 38-48.

Supartinah. 2013. Contribution of Nusantara Children Classic Literature for CultureVisioned Primary Education dalam jurnal 2nd International Seminar on Quality and Affordable Education (ISQAE 2013) 